\title{
The role of islamic work ethics in influencing organizational commitments mediated by intrinsic motivation of Islamic senior high school teachers
}

\section{Dhian Pratiwi}

Faculty of Business and Economics, Universitas Muhammadiyah Yogyakarta, Yogyakarta, Indonesia

Corresponding author: dhianpratiwi00@gmail.com
Article History

Received, 28 November 2019

Revised 1, 3 December 2019

Revised 2, 6 December 2019 Accepted, 10 December 2019

\begin{abstract}
Purpose: This study aims to examine the effect of Islamic work ethics in influencing organizational commitment through intrinsic motivation as a mediating variable

Design: Respondents of this study were 85 teachers at some Islamic high schools in Yogyakarta, Indonesia. This study implemented path analysis using SPSS.
\end{abstract}

Findings: The results of this study found that Islamic work ethics has a significant positive effect on organizational commitment. Besides that, intrinsic motivation is proven to be a mediating variable.

Originality/value: Work ethics is commonly found as a factor that influence organizational commitment. However, studies related to this topic are still limited in the Islamic context.

Keywords: intrinsic motivation, Islamic work ethics, organizational commitment

\section{Cite this:}

Pratiwi, D. (2019). The role of islamic work ethics in influencing organizational commitments mediated by intrinsic motivation of Islamic senior high school teachers. Asian Journal of Islamic Management, 1(2), 93-100. DOI: 10.1108/AJIM.vol1.iss2.art3

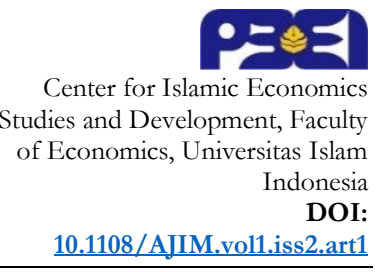

\section{Introduction}

Islamic education institutions, such as high school, may have a similar aspect compared to Islamic boarding school. Islamic school is an example of boarding school that follows the pattern of the western education system. The growth of Islamic high school contributes greatly to the formation of spiritual morals and character in society. In the era of globalization like today to face an increasingly modern world, it takes educators who have high Islamic work ethics. Islamic work ethics is a set of belief systems derived from the Qur'an and Sunnah derived from Islamic principles, which are related to hard work and work. With a work ethic that is in accordance with what is demanded and taught by aqidah, it is expected that educators are able to encourage quality and quality from within themselves in order to achieve organizational goals.

Motivation is a driver in an educator to do something actions that must be achieved in the organization. While intrinsic motivation has the meaning of motivation that comes from within individuals who arise because of their own desires without any encouragement from outside. Educators who already have intrinsic motivation will surely behave well and positively in doing a job. Because he will always try to provide the best in him with the aim of achieving the 
goals of the organization. Educators who have organizational commitment, of course, they will show a work attitude that is full of responsibility, attention to every job that is entrusted because they feel they have to give and do everything that is best for the organization. Therefore, organizational commitment is very influential on the performance of Human Resources in the organization.

Thus, the purposes of this research are: a). To analyze the role of Islamic work ethics in influencing organizational commitment. b). To analyze the role of Islamic work ethics in influencing intrinsic motivation.c). To analyze the role of intrinsic motivation on organizational commitment. d). To analyze the role of intrinsic motivation as a mediating variable of Islamic work ethics on organizational commitment.

\section{Literature Review and Hypothesis Development}

\section{Islamic Work Ethics}

Islamic work ethics in an Islamic perspective It has the meaning as a radiance of aqidah which is derived from the Islamic faith system as a basic attitude to life regarding work. Thus, the paradigm of Islamic work ethic can be built. While the characteristics of Islamic work ethics according to (Alwiyah, 2016), namely:

1) Work is a translation of faith.

2) Work based on knowledge.

3) Work by exploring Divine attributes and following His instructions.

According to Ali \& Al-Owaihan (2008), Islamic work ethics is an orientation that shapes and influences the involvement and participation of adherents in the workplace. Islamic work ethics views work as a means to improve economically, socially to advance the welfare of society and reaffirm to faith. Islamic work ethics is a motivating factor for someone to do his job well because the work is part of worship (Hidayat \& Tjahjono, 2015; Nurhidayah, et al., 2018).

\section{Organizational Commitment}

Organizational commitment is a psychological condition that can be in the form of wants, needs, or a sense of individual obligation to maintain membership in an organization (Palupi \& Tjahjono, 2016). There are 3 (three) dimensions of organizational commitment according to Allen \& Mayer (1990) namely:

a. Affective Commitment: Occurs when employees have a high emotional relationship with an organization so that employees want to continue to be part of the organization.

b. Continuous Commitment: Commitment that arises when employees continue to work in an organization because they need a salary, can also because they do not find another job so choose to stay in the organization.

c. Normative Commitment: Emerges from the values in employees who survive in the organization because of the awareness that commitment in the organization is what should be done.

\section{Intrinsic Motivation}

Motivation has the meaning of the word motive, which is something that results in an impulse or a condition that gives rise to an impulse. motivation can also be interpreted as a factor that can encourage someone to act in certain ways. Intrinsic motivation is a motivation that comes from within the individualwithout any influence from outside the individual (Handoko, 2012). There are several indicators that can form intrinsic motivation to produce good performance as desired including: a). Interest; b). There is a desire; c). The existence of ideals 


\section{Research Model and Hypothesis}

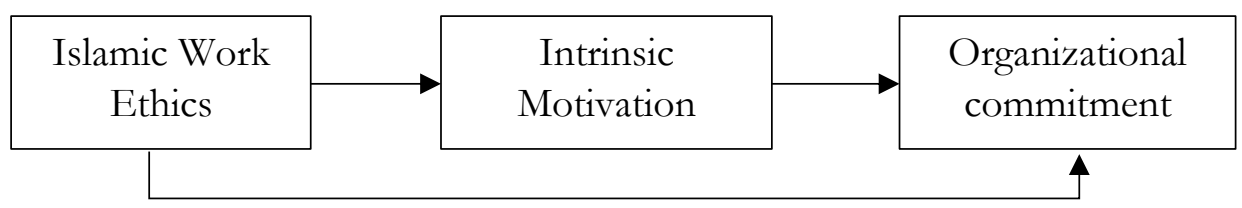

Figure 1. Research Model

Based on Figure 1, this research has four hypotheses:

H1: Islamic work ethics has a positive and significant effect on organizational commitment H2: Islamic work ethics has a positive and significant effect on intrinsic motivation H3: Intrinsic motivation has a positive and significant effect on organizational commitment

\section{Research Method}

\section{Object and Subject of Research}

This research was conducted to analyze how much influence the Islamic work ethic $(X)$, organizational commitment $(\mathrm{Y})$, and intrinsic motivation $(\mathrm{Z})$. The object of this research are teachers of Muhammadiyah High School III and VII in Yogyakarta.

\section{Types of Data}

In this study, the type of data used is primary data by distributing questionnaires directly to respondents.

\section{Data Instrument Quality Test}

\section{Validity test}

Validity test is done to measure the accuracy of the instruments used to measure with what is measured by researchers so that there is a match between the measuring instrument and the aspect being measured. In this study the validity calculation using SPSS 22.00 using Pearson product moment. The decision when $\mathrm{r}$ count $>\mathrm{r}$ table then the statement is valid. This validity test uses a significant level of 5\% (Ghozali I., 2013).

\section{Reliability test}

Reliability tests are carried out to prove the accuracy, consistency, and determination of the instrument in measuring the construct. This test is also useful to ascertain whether the data provided by respondents is true and reliable. The reliability calculation will use SPSS 22.00 software by seeing the reliability coefficient on alpha, the interpretation can be said to be reliable if the Cronbach Alpha value. 0.6 (Sekaran \& Bougie, 2017).

\section{Classical assumption test}

a. Normality Test

Normality test aims to determine whether each variable contributes.

b. Multicollinearity Test

According to Ghozali (2005), multicollinearity test aims to test whether the regression model found a correlation between independent variables.

c. Heterokedasticity Test

According to Ghozali (2013), heteroscedasticity test aims to test whether in the regression model there is an inequality of variance from the residuals of one observation to other 
remaining observations, whereby it is called homoscedasticity. On the other hand, if it is different, it is called heteroscedasticity.

\section{Hypothesis Testing}

a. Simple Linear Analysis

Simple regression analysis is an approach method for modeling the relationship between one dependent variable and one independent variable.Mathematically, a simple linear regression analysis model can be drawn as follows :

\section{$\mathrm{Y}=\mathrm{A}+\mathrm{BX}+\mathrm{e}$}

Where:

$\mathrm{Y}=$ dependent variable

$\mathrm{A}=$ intercept $/$ constant

$\mathrm{B}=$ regression coefficient

$\mathrm{E}=$ residual / error

b. Multiple Linear Analysis

In multiple linear regression, there are more than one independent variable. In research which requires the study of various variables that can influence one other variable, the choice of multiple regression analysis will be useful (Rahawati, Fajarwati, \& Fauziyah, 2016) Multiple linear equations:

$$
\mathrm{Y}=\beta 0+\beta 1 \mathrm{X} 1+\beta 2 \mathrm{X} 2+\beta 3 \mathrm{X} 3+\mathrm{e}
$$

Where:

$\mathrm{Y}=$ Organizational Commitment

$\mathrm{X} 1=$ Islamic Work Ethics

$\mathrm{X} 2=$ Intrinsic Motivation

$\beta 1 \beta 2 \beta 3=$ Regression Coefficient

$\beta 0=$ Regression Constants

\section{Result and Discussion}

The main objective of this study is to analyze the influence of Islamic work ethics on organizational commitment through intrinsic motivation as a mediating variable. The data in this study were collected through the distribution of questionnaires to 85 educators at Senior High Schools Muhammadiyah 3 and 7 Yogyakarta. Before the results of the questionnaire are examined, the validity and reliability should be tested in the first place. Validity Test is using the Pearson Product Moment Correlation formula and reliability test is using the Chonbach's Alpha formula. To answer the purpose of this study, several data analysis methods are used, namely descriptive statistical analysis, classical assumption analysis and regression analysis. Data analysis in this study used SPSS base 22 .

\section{Data Quality Test}

\section{Reliability test}

Table 1. Reliability Test

\begin{tabular}{lc}
\hline Variable & Cronbach's Alpha \\
\hline Islamic Work Ethics & 0,896 \\
Organizational Commitment & 0,716 \\
Intrinsic Motivation & 0,742 \\
\hline
\end{tabular}


From the results of the Table 1, it shows that the questionnaire declared reliable as referred to the Cronbach's Alpha value of Islamic work ethics variable (0.896), the organizational commitment variable $(0.716)$ and the intrinsic motivation variable $(0.742)$.

\section{Validity test}

The validity test uses the Pearson Product Moment Correlation formula by calculating the correlation between the scores of each question item with the total score. Islamic Work Ethics variable consists of 10 question items, variable organizational commitment consists of 9 question items and intrinsic motivation variable consists of 6 question items.

The results of testing using SPSS Base 22.0 show the results that the Pearson Correlation value of each instrument against the question item scores showed significant results. So it can be concluded that each question item from a variable is valid. So the data collected in this study deserves further analysis.

\section{Analysis of Classical Assumptions}

The classic assumption tests used in this study are the normality test, the multicollinearity test and the heteroscedasticity test.

\section{Normality test}

Normality test aims to test whether the dependent variable and independent variables in the regression table are normally distributed or not. A good regression model is one that has a normal distribution. The test was carried out using the Kolgomorov Smirnov method.

It can be concluded that seen from the results of normality testing using the Kolgomorov Smirnov method shows that the significant value of Islamic work ethics, organizational commitment to intrinsic motivation is 0.200 , which means it is greater than 0.05 so it can be concluded that the instrument is normally distributed.

\section{Multicollinearity test}

This multicollinearity test is to test and find out whether or not there is a deviation in the assumption of multicollinearity classifications, namely the existence of a linear relationship between the independent variables of the regression model. The way to test for the presence or absence of multicollinearity symptoms is to look at the value of tolerance and variance inflation factor (VIF). If the VIF value is below 10 then the regression model does not have multicollinearity symptoms, and vice versa if the VIF value is above 10 then the regression model has multicollinearity symptoms. The following are the results of multicollinearity tests that have been conducted done:

Table 2. Multicollinearity Test

\begin{tabular}{cccc}
\hline Variable & VIF & Tolerance & Results \\
\hline Islamic Work Ethics & 1,167 & 0,857 & There is no multicollinearity \\
Intrinsic Motivation & 1,167 & 0,857 & There is no multicollinearity \\
\hline
\end{tabular}

From Table 2, it can be seen that the multicollinearity test results have a VIF value $<10$ which means that the independent variable does not occur in multicollinearity.

\section{Heteroscedasticity test}

Heteroscedasticity test results with scatterplot method shows that the above points do not form a pattern and are located in an uncertain position, or abstract when viewed from the location and 
position of the points spread above and below the numbers 0 . Therefore, it can be concluded that Islamic Work Ethics, intrinsic motivation towards organizational commitment from the picture above does not occur Heteroscedasticity.

\section{Analisis Regresi}

Table 3. Regression Analysis

\begin{tabular}{llll}
\hline & $\begin{array}{l}\text { Islamic Work Ethics - } \\
\text { Organizational Commitment }\end{array}$ & $\begin{array}{l}\text { Islamic Work Ethics - Intrinsic } \\
\text { Motivation }\end{array}$ & $\begin{array}{l}\text { Intrinsic Motivation - } \\
\text { Organizational Commitment }\end{array}$ \\
\hline B & 0,301 & 0,378 & 0.257 \\
Sig & 0,006 & 0,000 & 0,017 \\
\hline
\end{tabular}

Based on Table 3, the result of the hypothesis test are:

Hypothesis 1: Based on the table above, it can be seen the significance value of Islamic work ethics on organizational commitment of 0.006 which is less than 0.05 . Thus, it can be concluded that Islamic work ethics significantly influence organizational commitment. Then, the value of $\beta$ Islamic Work Ethics is equal to 0.301 which means that the Islamic Work Ethics has a positive effect on organizational commitment. meaning that this happens because when employees have a high Islamic Work Ethic then the employee will increase loyalty to the organization through high commitment. As well as the education in Senior High Schools Muhammadiyah 3 and 7 Yogyakarta, where the results here show that educators express their concern for the educational institution and the belief to be willing to work as best as possible to achieve the purpose of Muhammadiyah 3 and 7 Yogyakarta High Schools.

Hypothesis 2: Based on the table above, it can be seen the significance value of Islamic work ethics on intrinsic motivation of 0,000 which is less than 0.05 . Thus, it can be concluded that Islamic work ethics significantly influence intrinsic motivation. Then, the value of $\beta$ Islamic Work Ethics is equal to 0.037 which means that Islamic Work Ethics has a positive effect on Intrinsic Motivation. This means that this happens because when employees work according to Islamic principles which work to seek God's blessing it will increase motivation from within individuals to work better. It is in line with the saying of the educators of Senior High School Muhammadiyah 3 and 7 Yogyakarta which depicts that Islamic Work Ethics is the the orientation shape and influences the involvement and participation of Educators in the workplace regarding hard work. The results of this research indicate that there is awareness to always be involved and to participate in organizations. Such awareness can exist without the need for outside encouragement or direction from the leadership.

Hypothesis 3: Based on the table above, it can be seen that the significance value of Intrinsic Motivation on Organizational Commitment is 0.017 , which is less than 0.05 . Means it can be concluded that Intrinsic Motivation has a significant effect on Organizational Commitment. Then, the value of Intrinsic Motivation is equal to 0.257 which means that Intrinsic Motivation has a positive effect on Organizational Commitment. It happens because when employees have high intrinsic motivation, it will increase employee loyalty to the organization. In line with that, the educators of Senior High School Muhammadiyah 3 and 7 in Yogyakarta, with their commitment, educators' beliefs to continuously develop and to become an important part in the organization would emerge without encouragement from outside but from inside the educators.

Hypothesis 4: To find out the value of mediation, you can also use the Sobel Test. The way to get a sobel test is to use a sobel calculator. From the results of the calculation of the sobel test, the value of Intrinsic Motivation between Islamic Work Ethics and Organizational Commitment 
is 2,039. The variable is said to be mediating if the value obtained from the multiple regression test is greater than 1.98 with significance of $5 \%$.The results of the study of Islamic work Ethics on Organizational Commitment through Initiative Motivation have a value of 2,039 greater than 1.98 which means mediating the effect of Islamic Work Ethics on Organizational Commitment, with the results of calculating pathways and multiple tests from Hypothesis 4 stating "Islamic Work Ethics affects Organizational Commitment through Intrinsic Motivation as a mediating variable" is accepted. which means to increase organizational commitment, employees pay attention not only to the direct influence of Islamic work ethics on organizational commitment, but also to the indirect effect of intrinsic motivation. Likewise, in Senior High School Muhammadiyah 3 and 7 Yogyakarta, educators carry out their duties in working with their own desires because they feel responsible and trustful for what is held in the organization.

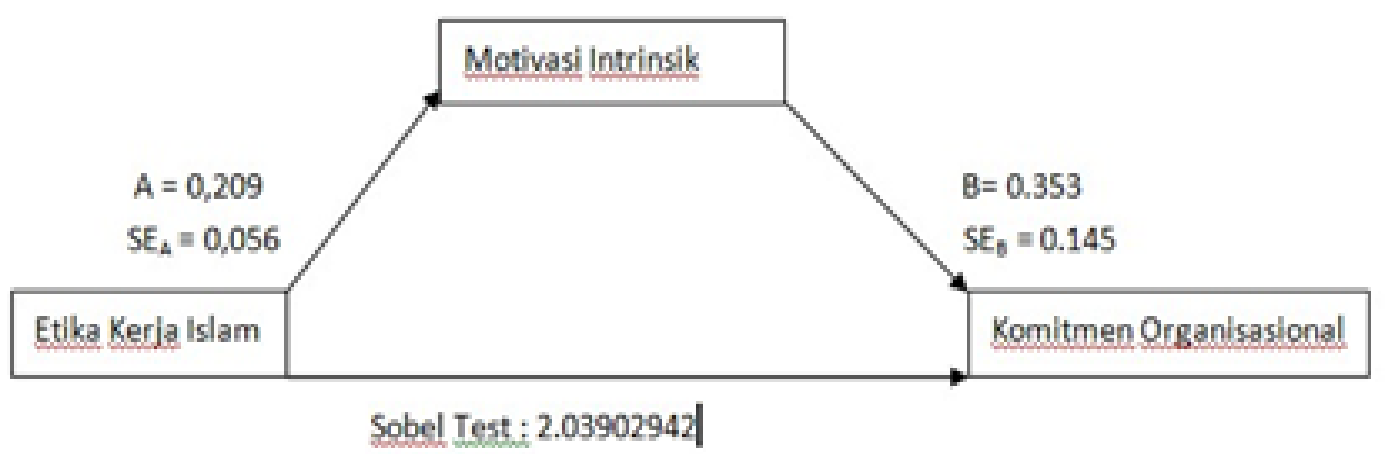

\section{Conclusion}

Based on the previous discussion, it is proven that Islamic work ethics has a positive and significant effect on organizational commitment mediated by intrinsic motivation. For further study, the researchers are expected to expand the scope of the research to be more evenly distributed in order to get maximum results, and can add other variables related to this research.

\section{References}

Ali, A. J., \& Al - Owaihan, A. (2008). Islamic Work Ethic: "a Critical Re-view". Cross Cultural Management an International Journal Vol.15 No.1 , 5-19.

Allen, N. J., \& Meyer, J. P. (1990). The measurement and antecedents of affective, continuance and normative commitment to the organization. Journal of occupational psychology, 63(1), 118.

Alwiyah, A. (2016). Peningkatan Etika Kerja Islam terhadap Komitmen Organisasi dan Kepuasan Kerja (Studi Kasus pada Staf Auditor Kantor Akuntan Publik Kota Semarang). Economica: Jurnal Ekonomi Islam, 7(2), 23-54.

Ghozali, I. (2013). Aplikasi Analisis Multivariate dengan Program IBM SPSS. Semarang: Universitas Diponegoro.

Handoko, T.H. (2012). Manajemen. Yogyakarta: BPFE UGM

Hidayat, S., \& Tjahjono, H. K. (2015). Peran etika kerja Islam dalam memperngaruhi motivasi intrinsik, kepuasan kerja dan dampaknya terhadap komitmen organisasional (studi empiris pada pondok pesantren modern di Banten). Jurnal Akuntansi dan Manajemen Akmenika, 12(2), 625-637.

Nurhidayah, S. A., Tjahjono, H. K., \& Susanto. (2018). The Influence Of Islamic Work Ethics Affectif Commitment And Altruism Againt Knowledge Sharing Behavior . International Journal Of Current Research, 10(08): 72508-72511 . 
Palupi, M. \& Tjahjono, H.K. (2016). A model of religiousity and organizational justice: the impact on commitment and dysfunctional behavior. The $27^{\text {th }}$ International Business Information Management Association Conference proceedings, Milan Italy, 1781-179.

Sekaran, U., \& Bougie, R. (2017). Metode Penelitian Untuk Bisnis Edisi 6. Jakarta: Salemba Empat.

Tjahjono, H.K. (2015). Metode Penelitian Bisnis. Yogyakarta: VSM MM UMY 